Completed applications were due to be received by the Inter-University Committee by March 31, 1959. Announcement of the final selections will be made before the end of this academic year.

\title{
APPOINTMENTS AND STAFF CHANGES
}

Yaroslav Bilinsky has been appointed instructor in political science at Douglass College, Rutgers University.

John C. Bollens has been appointed program director for urban studies at U.C.L.A.'s bureau of governmental research. He has been granted a one-semester leave from the department to resume his work as executive director of the Metropolitan Community Studies, Inc., Dayton, Ohio.

Lawrence $\mathrm{H}$. Chamberlain, who resigned as dean of Columbia College in June, 1958, has been named Joseph L. Buttenwieser professor of human relations and will resume his teaching in the department of public law in September, 1959.

Alfred B. Clubok, formerly of the University of Michigan, has accepted an appointment in the department of political science at the University of Florida.

Patrick J. Conklin, formerly of the University of Michigan, has been appointed assistant professor of political science at the University of Tulsa.

Richard W. Cottam, formerly with the Department of State, has joined the department of political science, University of Pittsburgh, as an assistant professor.

Robert A. Dahl has been appointed chairman of the department of political science, Yale University, for a three-year period.

Karl W. Deutsch, formerly at the Massachusetts Institute of Technology, has been appointed professor of political science at Yale University.

Richard Drake has been appointed acting head of the department of history and political science at Berea College.

Eugene Dvorin, who for the past several years has been research assistant in the bureau of government research at UCLA, has joined the department of government at Los Angeles State College as assistant professor in public administration.

Stephen T. Early, Jr., has been promoted to the rank of associate professor in the depart- ment of political science at DePauw University.

Ralph Eisenberg formerly of Princeton University and the New Jersey State Legislative Services Commission has been appointed assistant professor in the department of political science and bureau of public administration, University of South Carolina.

James W. Fesler, Alfred Cowles professor of government at Yale University, has been appointed editor-in-chief of the Public $A d$ ministration Review.

Lawrence H. Fuchs has been promoted to associate professor of politics at Brandeis University. He has been awarded a research grant by the Social Science Research Council. Professor Fuchs will spend 1958-59 in Hawaii examining the political behavior of this multiethnic community.

William R. Gable, research associate in the University of Michigan's institute of public administration, has been appointed executive secretary of the Metropolitan Problems Study Commission appointed by Governor G. Mennen Williams.

Gilbert Frank Gilchrist, of the department of political science of the University of the South, has been advanced to associate professor of political science.

Edward A. Goernew has been appointed an instructor in the department of political science at Yale University.

Fred I. Greenstein has been appointed to the department of political seience at Yale University to teach in the program of directed studies.

Brigen K. Gupta has been appointed lecturer in the department of government at Southern Illinois University.

Joseph Hamburger has been promoted to an assistant professor of political science at Yale University.

Richard H. Hedrich has been appointed as an instructor on the staff of the department of government and politics at the University of Maryland for the spring semester of 1959 . 
Stanley Hopper is beginning his second year with Los Angeles State College, while completing his $\mathrm{Ph}$.D. at Harvard.

John P. Hummon, formerly of the University of Michigan, has accepted a position with the Department of the Navy.

Morton A. Kaplan of the University of Chicago has been appointed chairman of the committee on international relations at the University of Chicago.

Herbert Kaufman has been promoted to associate professor of political science at $Y$ ale University.

Norman Kogan has been promoted to associate professor of government and international relations at the University of Connecticut, Storrs, Connecticut.

Robert E. Lane, associate professor of political science at Yale University, has been appointed director of graduate studies.

Robert Langer, visiting professor of political science and international relations at Queens College for a number of years, retires in June.

Shirley J. Lehmann is now an instructor in political science at Vassar College.

George A. Malley has been appointed an instructor in political science at Yale University for the academic year 1958-59.

Albert B. Martin, chairman of the departmental committee of the department of political science, University of Pittsburgh, has been appointed associate dean of the school of liberal arts. Chairmanship of the departmental committee has been assumed by Holbert $\mathrm{N}$. Carroll.

Geoffrey J. Martin has been appointed instructor in the department of government, University of Miami.

Albert A. Mavrinac, formerly lecturer on government at Harvard University, has been appointed full professor of history and government at Colby College and chairman of the department. During the academic year 1958-59 he is on leave to serve as Fulbright Professor at the Universities of Rennes and Montepelier, France, where he is lecturing on American polities.

Jack Misner is the new chairman of the department of government at Los Angeles State College.

Robert M. Northrop, formerly of Allegheny
College, has been appointed an assistant professor at Rutgers University.

Vincent Ostrom has been appointed program director for policy studies at U.C.L.A.'s bureau of governmental research.

Norman D. Palmer, University of Pennsylvania, visited Pakistan in August and September, 1958, on an inspection trip to review the work being carried on at the institute of public and business administration in Karachi, which the University of Pennsylvania is helping to establish under a contract with the International Cooperation Administration. Professor Palmer is coordinator of the Karachi Project.

Addison Potter and Jack Misner of Los Angeles State College were promoted to associate professors of government.

Geddes W. Rutherford has been promoted to the rank of associate professor of political science.

Milton Sacks has been promoted to assistant professor of politics at Brandeis University.

Karl Schmitt, formerly of the Division of Research for the American Republics, Department of State, has accepted an appointment as assistant professor of government at The University of Texas.

Irving $P$. Schwartz has been appointed as a lecturer in political science at Queens College. Dr. Schwartz is also a member of the president's staff at Queens.

Bert A. Smith has been appointed assistant to the director of the bureau of government research at the University of Missouri.

Hoke L. Smith, who received the $\mathrm{Ph}$.D. degree from Emory University in June 1958, has been appointed an assistant professor in the political science department at Hiram College, Hiram, Ohio.

Frederick C. Spiegel has been promoted to the rank of assistant professor at the University of Missouri.

Gilbert Y. Steiner has been appointed director of the institute of government and public affairs at the University of Illinois.

Robert S. Sullivant, who has been connected with the research project of Georgetown University, joined the staff of the political science department at DePauw University at the beginning of the second semester.

John P. Vloyantes of the department of 
political science at Pacific University has been promoted to the rank of associate professor.

William R. Willoughby has been promoted to full professor at St. Lawrence University.

James Wilson has joined the department of government of Bowdoin College as instructor. He will also have charge of the bureau for research in municipal government.

Raymond E. Wolfinger has been appointed to the department of political science at Yale University to teach in the program of directed studies.

Peter Woll has received his doctoral degree from Cornell and has accepted an appointment as instructor in the department of political science at U.C.L.A. He is to be secretary of the committee on master of public administration degree program.

Frank Wray of Berea College has been promoted to associate professor.

Victor Zitta, formerly of the University of Michigan, has accepted an appointment at Gonzaga College.

Robert Zuckerman, formerly associate editor of the Chronicle of United Nations Activities, has been appointed assistant professor of government, University of Miami.

Stephen K. Bailey of Princeton University was appointed a visiting professor at the University of Pennsylvania for the academic year 1958-59.

Leonard Binder of U.C.L.A. is in Iran studying religious groups on a grant from the Social Science Research Council.

Thompson Black, Jr. is serving as acting chairman of the division of social science at Los Angeles State College, where he is associate professor of government.

Henry L. Bretton, associate professor of political science at the University of Michigan, has received a grant from the Faculty Research Fund to enable him to visit Nigeria during the summer of 1959 .

Henry C. Bush has accepted an assignment with the International Cooperations Administration as public administration adviser to the Ministry of Home Affairs of the Republic of Indonesia. $\mathrm{He}$ will be located in Malang with Djakarta as his official address.

Paul Camp, adjunct professor in the school of government and public administration of
The American University received the Merit Citation for 1958 from the Natlonal Civil Service League in recognition of an outstanding career in the public service.

David T. Cattell has been granted one-half year sabbatical leave from the department of political science at U.C.I.A. in order to accept a grant from the Social Science Research Council. He will pursue research in Finland and elsewhere in Europe on the topic: The Soviet Union and International Law.

C. W. Cassinelli, of Whitman College, is visiting associate professor of political science at the University of Wisconsin during the current academic year.

David A. Cayer served as a lecturer in political science, Rutgers University, during the first semseter, 1958-59.

Miss Dorothy I. Cline, assistant professor of government at the University of New Mexico, on November 4, 1958 was elected County Commissioner of Bernalillo County. This County includes the city of Albuquerque. Because Miss Cline received the highest number of votes, she will become the Chairman of Commissioners. She is the first woman to bold this office in New Mexico.

Robert Clute, formerly of Duke University, is serving as visiting assistant professor at Tulane this year.

James S. Coleman of U.C.L.A. participated in a meeting of the Comparative Politics Committee of the Social Science Research Council in New York on 15 November. He also participated in a meeting of the Senior Staff of the Human Environments in Central Africa Project of the National Academy of Sciences in Washington, D.C., 24-26 November.

Thomas I. Cook, of the Johns Hopkins University, has been appointed visiting professor of government at Columbia for the spring session, 1959.

Cornelius P. Cotter, Stanford University, has been awarded a National Committee Faculty Fellowship and will serve as special consultant to the chairman of the Republican National Committee. This is a one-year fellowship (January-December, 1959) sponsored by the Citizenship Clearing House and the National Committees of both political parties.

David J. Dallin has been appointed a visitIng professor for 1958-59 at the University of Pennsylvania.

Marcus Daly, lecturer in political science at 
Fordham University, has been named chairman of the intergovernmental committee for European Migration.

Bernard N. Darbyshire of the University of Geneva has served as visiting lecturer in government at The University of Texas during the fall semester 1958-59. Mr. Darbyshire is a student and consultant in the field of oil and atomic energy economics.

Alfred deGrazia, formerly of Stanford University, offered a seminar in comparative government at Rutgers University during the first semester, 1958-59.

Alfred Diamant of the University of Florida is visiting associate professor in the department of political science at Yale University for the academic year 1958-59.

Raymond S. Dodds, Inspector for the Public Service Board, New South Wales, Australia, is spending the academic year at the University of Illinois as research associate. $\mathrm{He}$ is studying comparative state administrative techniques in his country and the United States.

Paul Dolan, held a summer fellowship in social gerontology at the University of Connecticut under auspices of the University of Michigan.

Chester B. Earle of the school of government and public administration of The American University served during the summer, 1958, as consultant on the social and economic costs of air pollution for the Department of Health, Education, and Welfare.

Murray Edelman will be on leave from the University of Illlnois during the spring semester in order to teach at the University of Texas.

Henry W. Ehrmann of the University of Colorado on sabbatical leave for 1958-59, taught under the auspices of the Fulbright program at the Nice Center for Juridical Studies of the University of Aix-en-Provence. Currently he is lecturing at the Institutes of Politics of the Universities of Bordeaux, Grenoble, and Paris.

Ernest A. Engelbert is serving as director for Revision of the California State Education Code. This project is being undertaken by the bureau of governmental research in cooperation with professors of law, education and public administration from seven California universities and colleges.

Bernard D. Fall, associate professor in the department of government, Howard University, attended the 13th Conference of Pacific Institutes at Lahore (Pakistan) as a member of the French Center of Foreign Policy Studies in February 1958. Dr. Fall was elected local arrangements chairman for the annual meeting of the Association of Asian Studies, to be held in Washington, D.C., in April 1959.

Glenn Fischer of North Dakota State Agricultural College is visiting assistant professor of government and public affairs at the University of Illinois this year, while studying financial problems of the state of Illinois.

Manuel R. Garcia-Mora, professor of law at the University of Detroit has been awarded a Fulbright lectureship at the University of San Marcos, Lima, Peru from June, 1959, to January, 1960.

Thomas W. Gill has been appointed lecturer in the school of government and public administration of The American University.

John Gillespie of Tulane University is on leave of absence to serve this year as executive secretary of the Duke Commonwealth Studies Center.

Moris A. Greene, professorial lecturer in the school of government and public administration of The American University participated in 1958 in the United Nations Consultative Committee on Administrative Questions.

Harry S. Hall is teaching in the political science department of Temple University during the year 1958-59.

Paul Y. Hammond, assistant professor of political science at Yale University, is on leave of absence for the academic year 1958-59.

Ervin P. Hexner, recently retired from the International Monetary Fund, is a visiting professor at the Pennsylvania State University.

Henry M. Holland, from the University of Washington, is teaching at the Pennsylvania State University.

Charles A. Hollister has been granted an extension of his leave of absence for one more year to be assistant research director, bureau of municipalities, department of internal affairs, at Harrisburg, $\mathbf{P a}$.

John Perry Horlacher, University of Pennsylvania, served as chairman of the National Assembly on Mental Health Education which was held at Cornell University in September and addressed the annual convention of the 
National Association for Mental Health held at Kansas City in November.

John A. Houston of Knox College will serve as visiting professor of political science at the University of Michigan during the summer of 1959.

C. Herschel Jones has been granted a twoyear leave of absence to be coordinator, Intern-Trainee Program, New York Department of Civil Service, Albany, New York.

Willmoore Kendall, associate professor of political science at Yale University, is on leave of absence for the academic year 1958-59, and is teaching at Stanford University.

Richard H. Kennington has been appointed visiting lecturer of the graduate faculty of the New School for Social Research, New York for 1958-59. He is lecturing in the political science and in the philosophy departments.

Magid Khadduri is visiting professor of government at Columbia for the academic year 1958-59.

Marshall Knappen is visiting professor in political science at the University of Delaware during the academic year 1958-59.

Lord Lindsay of Birker of the Australian National University has been appointed visiting lecturer of political science at Yale University for the first term of 1958-59.

Henry Mason, associate professor of political science at Tulane University, has a Fulbright lectureship for 1958-59 at the University of Innsbruck, Austria.

Neil A. McDonald, Douglass College, Rutgers University, was recently elected president of the municipal council of Edison Township, New Jersey.

Dean McHenry of U.C.L.A. has been granted partial leave from the department to accept an appointment as academic assistant to the president of the University of California.

Robert T. McKenzie of the London School of Economics is visiting lecturer of political science at Yale University for the first term of the academic year 1958-59.

Eugene J. Meehan is a lecturer in political science at Rutgers University for the year 1958-59.

Robert Neumann has been appointed acting director of the institute of international and foreign studies at the University of California, Los Angeles.

Robert E. Osgood of the University of Chicago is on leave from the University from April through June, 1959, as NATO visiting professor at the University of Manchester in Manchester, England.

Don Peretz, a political writer on the Middle East, is teaching a course on the Middle East at Vassar College during the second semester of the current academic year.

Miss Frances Perkins, former Secretary of Labor, spent two months on the campus of the University of Illinois as George A. Miller visiting professor, sponsored by the department of political science, the institutes of labor and industrial relations and of government and public affairs, as well as by the college of law and the school of social work. She conducted a series of seminars and offered a number of public discussions on politics, politicians and public policy questions.

Paul J. Piccard of The Florida State University has accepted an appointment as visiting associate professor at the University of California, Los Angeles for the second semester, 1958-59.

Roy Pierce, assistant professor of political science at the University of Michigan, will teach in the department of public law and government of Columbia University during the summer of 1959.

Pitman Potter, professor emeritus of international law at American University has returned to Geneva to carry on research, writing and lecturing. Mrs. Potter is an economic officer at the United States Consulate.

Lucian W. Pye, assistant professor of political science at the Massachusetts Institute of Technology, has been appointed visiting lecturer of political science at Yale University for the second term of $1958-59$.

Leo C. Riethmayer, professor of political science and director of the graduate program in public administration at the University of Colorado, and mayor of the City of Boulder, has been elected president for 1959 of the Denver Chapter of the American Society for Public Administration.

Fred W. Riggs, associate professor of government at Indiana University, has joined the 
faculty of the institute of public administration, University of the Philippines, for the academic year 1958-59 as a visiting professor, under the institute's grant from the Rockefeller Foundation. He arrived in June, after a year in Thailand studying Thai politics and administration under a research grant from the Social Science Research Council Committee on Comparative Politics.

John P. Roche, professor of politics and chairman of the department of politics at Brandeis University, has been appointed dean of the faculty for 1958-59.

Landon G. Rockwell of Hamilton College is serving as visiting lecturer in government at The University of Texas during the spring semester.

David N. Rowe, professor of political science at Yale University is the recipient of the Ford Rotating Research Professorship for the year 1958-59. He is studying the impact of American economic policies on agrarian areas, using Taiwan as a case study.

Benjamin Schoenfeld is on leave from Temple University during the academic year 1958-59 as a Fulbright professor of political science at the University of Kerala, Trivandrum, Kerala, South India. He is also lecturing at the Law School at Cochin.

Catheryn Seckler-Hudson and Charles $H$. Goodman of the school of government and public administration of The American University presented papers at the Tenth Conference on Personnel Management for Executives in Washington, D.C.-October 27-November 7 , 1958. Dean Seckler-Hudson spoke on "Problems of Delegation in a Large Organization," and Professor Goodman's topic was "Human Relations in Management."

J. David Singer, visiting assistant professor of political science at the University of Michigan, has received a grant from the Phoenix Memorial Fund to study post World War II disarmament negotiations.

Carl O. Smith has been named second vicechairman of the Detroit Metropolitan Regional Planning Commission.

Norman Stamps of Rutgers has accepted an appointment as visiting associate professor of political science at the University of California, Los Angeles, for the fall semester.

Paul G. Steinbicker, director of the depart- ment of government at St. Louis University, was elected president of the Missouri Political Science Association at its annual meeting at Central Missouri State College, Warrensburg, Missouri, on October 31.

Ronald M. Stout has resumed his teaching responsibilities at Colgate University after having been on leave for two years serving as Coordinator of the Intern-Trainee Program administered by the New York State Department of Civil Service.

James D. Teller, adjunct professor in the school of government and public administration, The American University, served this year as chairman, United States Delegation, Working Party of Technical Experts on the NATO Air Forces Personnel Classification System, in London, and as consultant to the French Air Force on personnel classification systems.

Raymond Uhl has returned to the University of Minnesota for a second year as visiting professor of political science.

Frederick M. Watkins of Yale was visiting professor of government at Columbia during the Fall Term.

Norman Wengert, of the University of Maryland, will be on leave of absence in the spring semester in order to serve as guest professor at Cornell University; in the summer he will be undertaking a research program with the assistance of a grant from the General Research Board of the University of Maryland.

Jay Westcott of Syracuse University will serve as visiting professor of political science at the University of Michigan during the summer of 1959 .

Howard B. White, professor of political science of the Graduate Faculty of the New School of Social Research, New York, has been given a leave of absence for 1958-59. He is doing research work on "The Political Philosophy of Shakespeare" under a grant from the Rockefeller Foundation.

Francis G. Wilson will be on leave from the University of Illinois during the spring semester to teach at Notre Dame University.

Stanley J. Zyzniewski, returned in January after spending four months as a visiting regearch fellow at Warsaw University, continuing his research into 19 th century RussoPolish relations. 